\title{
Photocatalytic Degradation of Methyl Violet with $\mathrm{TiSiW}_{12} \mathrm{O}_{40} / \mathrm{TiO}_{2}$
}

\author{
Shuijin Yang, Yulin Xu, Yongkui Huang, Guohui Zhou, Zhiyuan Yang, \\ Yun Yang, and Guohong Wang \\ College of Chemistry and Environmental Engineering, Hubei Key Laboratory of Pollutant Analysis \& Reuse Technology, \\ Hubei Normal University, Huangshi 435002, China
}

Correspondence should be addressed to Shuijin Yang; yangshuijin@163.com

Received 9 January 2013; Revised 23 March 2013; Accepted 23 March 2013

Academic Editor: Jiaguo Yu

Copyright (C) 2013 Shuijin Yang et al. This is an open access article distributed under the Creative Commons Attribution License, which permits unrestricted use, distribution, and reproduction in any medium, provided the original work is properly cited.

The photocatalytic degradation of methyl violet using $\mathrm{TiSiW}_{12} \mathrm{O}_{40} / \mathrm{TiO}_{2}$ as a novel eco-friendly catalyst under simulated natural light irradiation was investigated. The physical characterizations were carried out by TG/DTA, FT-IR, XRD, and UV-visible spectra. The effects of the initial methyl violet concentration, the solution $\mathrm{pH}$, and catalyst dosage on the photocatalytic degradation rate of methyl violet were also examined. The results demonstrated that at optimal condition (initial concentration of methyl violet is $20 \mathrm{mg} / \mathrm{L}$, catalyst dosage is $0.3 \mathrm{~g}$, and the $\mathrm{pH}$ is 5.5), the degradation rate of methyl violet is as high as $82.4 \%$ after $3 \mathrm{~h}$ under simulated natural light irradiation. The reaction of photocatalysis for methyl violet can be expressed as first-order kinetic model.

\section{Introduction}

With the remarkable steady growth of people's living standard, organic dyes, which have been widely used in industry have become a concern because of their byproducts that constitute a serious risk for human health due to their high toxicity $[1,2]$. However, they are difficult to be treated through generic chemical methods and biological techniques, such as condensation, ultrafiltration, membrane separation, bacterial, and adsorption $[3,4]$. Hence, the treatment of organic pollutants has become a serious problem in environmental and chemical fields $[5,6]$. It is noteworthy that the new opportunities and challenges in water treatment have led to the development of photocatalytic oxidation technology, which has the potential to completely oxidize organic compounds to $\mathrm{CO}_{2}, \mathrm{H}_{2} \mathrm{O}$, and other inorganic substances [79]. Photocatalytic oxidation technology with semiconductor materials such as $\mathrm{TiO}_{2}, \mathrm{TiOX}, \mathrm{Fe}_{2} \mathrm{O}_{3}$, and $\mathrm{SrTiO}_{3}$ as the catalyst has been investigated widely by several authors [1013]. Among these functional materials, $\mathrm{TiO}_{2}$ has received the greatest interest in the field of photocatalysis technology. $\mathrm{TiO}_{2}$ used in photocatalytic water treatment has many excellent properties such as high activity, chemical stability, and nontoxicity. Other than these, photocatalytic activity of $\mathrm{TiO}_{2}$ can be turned by various chemical methods to obtain visible light response [14].

Polyoxometalates (POMs) constituted by transition metals in their highest oxidation states and oxoanions have been extensively studied as catalysts for a wide range of reactions. They have the similar photochemical characteristics with $\mathrm{TiO}_{2}$ and can be activated by the light in the near ultraviolet (UV) or the visible region, and hence they are also used as photocatalysts in wastewater treatment [15]. POMs should be supported on a support like molecular sieves, carbon, or transition metal oxide to overcome their shortcomings, such as low surface area $\left(1-10 \mathrm{~m}^{2} / \mathrm{g}\right)$, low thermal stability, and high solubility, which limit their industrial application. $\mathrm{TiO}_{2}$ was also an ideal support because of its higher surface area, chemical inertness, controlled porosity, and well dispersal for POMs while retaining the structure [16].

Since nearly $5 \%$ of the solar energy incident on the Earth's surface lies in the ultraviolet light region, it is essential to use natural light efficiently to drive photocatalytic oxidation of organic dyes. In order to achieve the goal, we attempt to develop novel functional materials with a visible light response. In this paper, the preparation of $\mathrm{TiSiW}_{12} \mathrm{O}_{40} / \mathrm{TiO}_{2}$ composite was reported, and the photocatalytic degradation 
of methyl violet with the catalyst under simulated natural light irradiation was investigated.

\section{Experimental}

2.1. Preparation of Catalyst. The catalyst was prepared using $\mathrm{Ti}(\mathrm{OH})_{4}$ and $\mathrm{H}_{4} \mathrm{SiW}_{12} \mathrm{O}_{40} \cdot 21 \mathrm{H}_{2} \mathrm{O}$ as the starting materials. $\mathrm{H}_{4} \mathrm{SiW}_{12} \mathrm{O}_{40} \cdot 21 \mathrm{H}_{2} \mathrm{O}(10.0 \mathrm{~g}, 3.0707 \mathrm{mmol})$ was dissolved in $40 \mathrm{~mL}$ of water, and the solution was heated to near $100^{\circ} \mathrm{C}$. Then, $\mathrm{Ti}(\mathrm{OH})_{4}(1.0 \mathrm{~g}, 8.6260 \mathrm{mmol})$ was slowly added to the boiling solution, and the resulting mixture was refluxed for $3 \mathrm{~h}$. In this process, water was added to the solution to prevent it from searing. After drying at $100^{\circ} \mathrm{C}$ for $12 \mathrm{~h}$, the white catalyst was obtained.

2.2. Characterization. The thermal stability of the catalyst was examined by means of DTA with a Netzsch STA 449 thermal analysis system at a heating rate of $10^{\circ} \mathrm{C} / \mathrm{min}$ from 20 to $700^{\circ} \mathrm{C}$ in air atmosphere. The FT-IR spectra of the samples in $\mathrm{KBr}$ matrix were recorded on a Nicolet $5700 \mathrm{FT}$ IR spectrometer in the range $400-4000 \mathrm{~cm}^{-1}$. The X-ray powder diffraction pattern of the samples was measured by a Bruker AXS D8-advanced diffractometer (Bruker, Germany) employing $\mathrm{Cu} \mathrm{K}_{\alpha}$ radiation.

2.3. Activity Test. For the evaluation of catalyst activity, the catalyst was suspended in an aqueous solution of methyl violet in a Pyrex reactor. The photoreactor was designed with a light source surrounded by a quartz jacket. Simulated sunlight irradiation was provided by a $500 \mathrm{~W}$ xenon lamp (Nanjing Xujiang Electromechanical Factory, China) and the intensity of the lamp was $1200 \mu \mathrm{mol} \cdot \mathrm{m}^{-2} \cdot \mathrm{s}^{-1}$. Solution $\mathrm{pH}$ was adjusted with dilute aqueous $\mathrm{HCl}$ and $\mathrm{NaOH}$ solutions. The system was cooled by circulating water and maintained at room temperature. Before irradiation, the suspensions were magnetically stirred in the dark for $30 \mathrm{~min}$ to reach the adsorption-desorption equilibrium of organic dyes on catalyst surface. At given time intervals, about $3 \mathrm{~mL}$ suspension was continually taken from the photoreactor for subsequent methyl violet concentration analysis after centrifuging. Decreases of the methyl violet concentrations were monitored via a UV-visible spectrometer (Hitachi U-3010, Japan). The degradation yield of organics was calculated by the following formula:

$$
\text { Degradation yield }(\%)=\left(\frac{A_{0}-A}{A_{0}}\right) \times 100 \text {, }
$$

where $A_{0}$ and $A$ referred to the absorbance of RhB before and after reaction, respectively.

\section{Results and Discussion}

3.1. Characterization of the Catalysts. The DTA curve of the catalyst is shown in Figure 1. The pyrolysis proceeds mainly in three steps. The endothermic peaks on the DTA curve at about $98.3^{\circ} \mathrm{C}$ correspond to the loss of the adsorbed water. The broad endothermic peak at about $258.8^{\circ} \mathrm{C}$ is associated with the loss of coordination water in HPA, and the loss

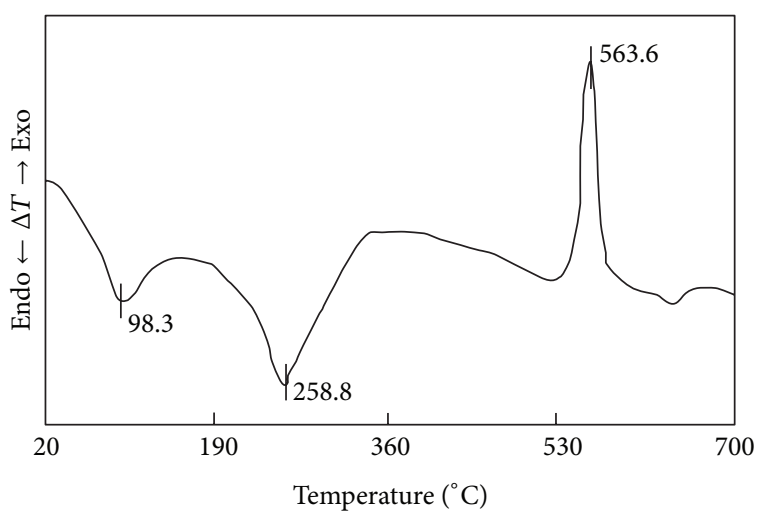

FIGURE 1: DTA curve of the catalyst.

is complete at $350^{\circ} \mathrm{C}$, which is the activation temperature of $\mathrm{TiSiW}_{12} \mathrm{O}_{40} / \mathrm{TiO}_{2}$. Finally, $\mathrm{TiSiW}_{12} \mathrm{O}_{40} / \mathrm{TiO}_{2}$ starts to decompose and its Keggin structure collapses, as seen from the sharp exothermic peak at $563.6^{\circ} \mathrm{C}$.

IR spectra of $\mathrm{TiO}_{2} \cdot x \mathrm{H}_{2} \mathrm{O}, \mathrm{H}_{4} \mathrm{SiW}_{12} \mathrm{O}_{40} \cdot x \mathrm{H}_{2} \mathrm{O}$, and $\mathrm{TiSiW}_{12} \mathrm{O}_{40} / \mathrm{TiO}_{2}$ are shown in Figure 2. The infrared spectra characteristic absorption peaks of $\mathrm{TiO}_{2}$ are explored at $1401 \mathrm{~cm}^{-1}$ and of $\mathrm{H}_{4} \mathrm{SiW}_{12} \mathrm{O}_{40} \cdot 21 \mathrm{H}_{2} \mathrm{O}$ at $1631,984,935,785$, and $549 \mathrm{~cm}^{-1}$. In the infrared spectrum of $\mathrm{TiSiW}_{12} \mathrm{O}_{40} / \mathrm{TiO}_{2}$, the absorption bands at 1618, 1021, 984, 928, 885, 791, and $543 \mathrm{~cm}^{-1}$ can be assigned to the bending vibrations of $\mathrm{H}-$ $\mathrm{O}-\mathrm{H}$ bond and the stretching vibrations of Si-O-Si, W-Od, Si-O, W-Ob-W, W-Oc-W, and Si-O-Si bonds, respectively. The stretching vibrations of Ti-O at $1401 \mathrm{~cm}^{-1}$ in titanium hydroxide decrease in the composite of $\mathrm{TiSiW}_{12} \mathrm{O}_{40} / \mathrm{TiO}_{2}$. Similar bands in the region of $935-543 \mathrm{~cm}^{-1}$ confirmed the presence of red shift of absorption peaks at the base of $\mathrm{H}_{4} \mathrm{SiW}_{12} \mathrm{O}_{40} \cdot 21 \mathrm{H}_{2} \mathrm{O}$. These indicate that the Keggin structure of $\mathrm{H}_{4} \mathrm{SiW}_{12} \mathrm{O}_{40} \cdot 21 \mathrm{H}_{2} \mathrm{O}$ [17] was maintained after compounding at the surface of support.

XRD spectra of $\mathrm{TiO}_{2}, \mathrm{H}_{4} \mathrm{SiW}_{12} \mathrm{O}_{40} \cdot x \mathrm{H}_{2} \mathrm{O}$, and $\mathrm{TiSiW}_{12} \mathrm{O}_{40} / \mathrm{TiO}_{2}$ are shown in Figure 3. The X-ray powder patterns of $\mathrm{TiO}_{2}$ calcinated at $350^{\circ} \mathrm{C}$ for $3 \mathrm{~h}$ show the anatase structure. The comparison of XRD patterns with $\mathrm{H}_{4} \mathrm{SiW}_{12} \mathrm{O}_{40} \cdot 21 \mathrm{H}_{2} \mathrm{O}$ reveals that the salt $\mathrm{TiSiW}_{12} \mathrm{O}_{40}$ also shows the Keggin structure [17], which is in accordance with the results of IR spectrum analysis.

\subsection{Investigation of Photocatalytic Activity of Catalysts}

3.2.1. Comparison of Photocatalytic Activity of Catalysts. In order to observe the catalytic activity of $\mathrm{TiSiW}_{12} \mathrm{O}_{40} / \mathrm{TiO}_{2}$, comparison of photocatalytic activity of catalysts was carried out at the initial methyl violet concentration of $20 \mathrm{mg} / \mathrm{L}, \mathrm{pH}$ 5.5 , and $0.3 \mathrm{~g}$ of catalyst. The results showed that, after $2.5 \mathrm{~h}$ irradiation under the same conditions, no obvious methyl violet degradation was observed without any catalyst or light. However, in the presence of $\mathrm{TiSiW}_{12} \mathrm{O}_{40} / \mathrm{TiO}_{2}$ without any light, the degradation yield of methyl violet is about $11.9 \%$, while with $\mathrm{TiSiW}_{12} \mathrm{O}_{40} / \mathrm{TiO}_{2}$ under simulated natural light irradiation the degradation yield can reach to $70.5 \%$. So the photodegradation reaction of methyl violet in the presence 


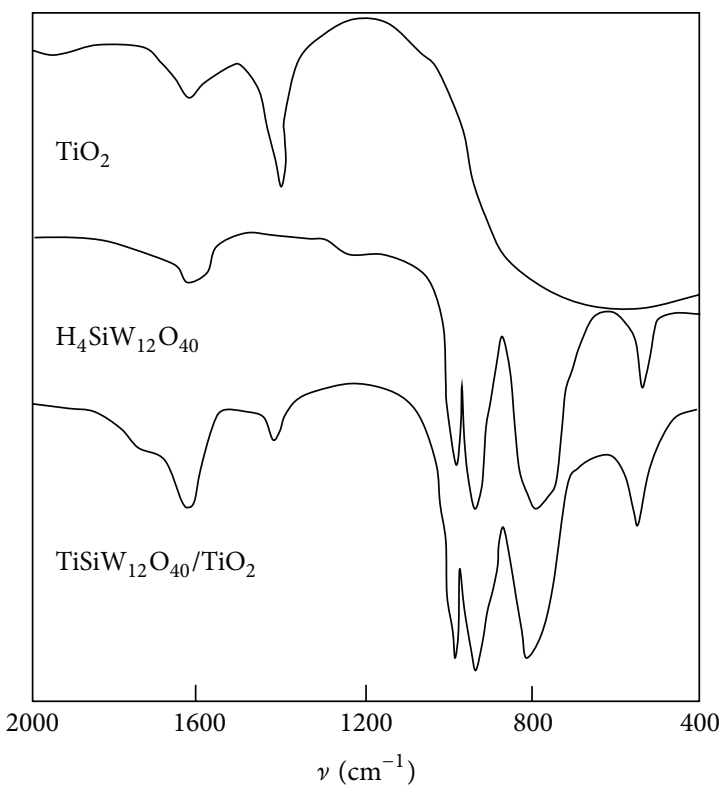

Figure 2: IR spectra of $\mathrm{TiO}_{2} \cdot x \mathrm{H}_{2} \mathrm{O}, \mathrm{H}_{4} \mathrm{SiW}_{12} \mathrm{O}_{40} \cdot x \mathrm{H}_{2} \mathrm{O}$, and $\mathrm{TiSiW}_{12} \mathrm{O}_{40} / \mathrm{TiO}_{2}$.

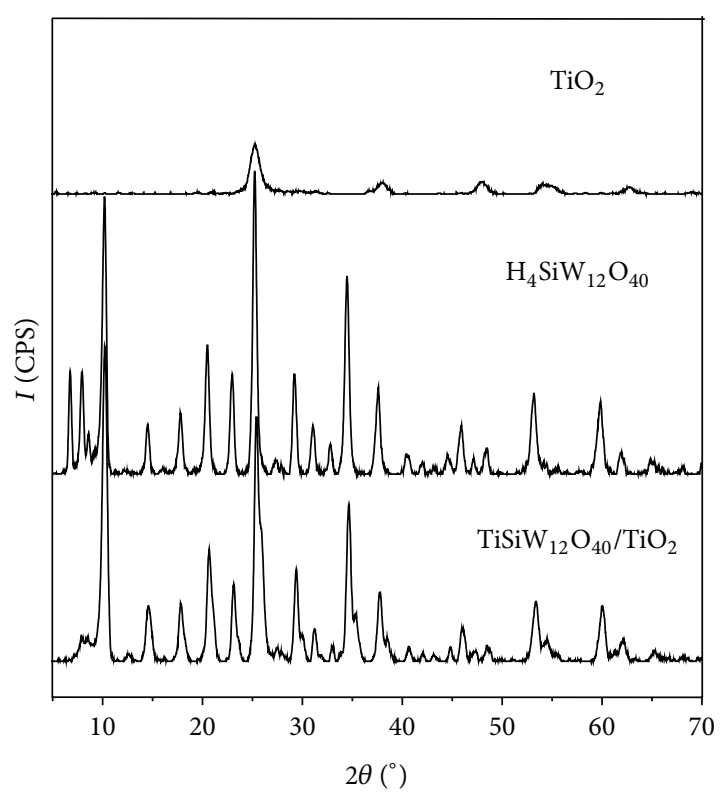

Figure 3: XRD spectra of $\mathrm{TiO}_{2}, \mathrm{H}_{4} \mathrm{SiW}_{12} \mathrm{O}_{40} \cdot x \mathrm{H}_{2} \mathrm{O}$, and $\mathrm{TiSiW}_{12} \mathrm{O}_{40} / \mathrm{TiO}_{2}$.

of TiSiW ${ }_{12} \mathrm{O}_{40} / \mathrm{TiO}_{2}$ under simulated natural light irradiation is more effective than that of $\mathrm{TiSiW}_{12} \mathrm{O}_{40} / \mathrm{TiO}_{2}$ without any light.

3.2.2. Effect of the Initial Concentration of Dye. To investigate the influence of initial concentration on the degradation efficiency of methyl violet, the initial concentration was varied from 5 to $40 \mathrm{mg} / \mathrm{L}$, keeping the other experimental conditions constant.

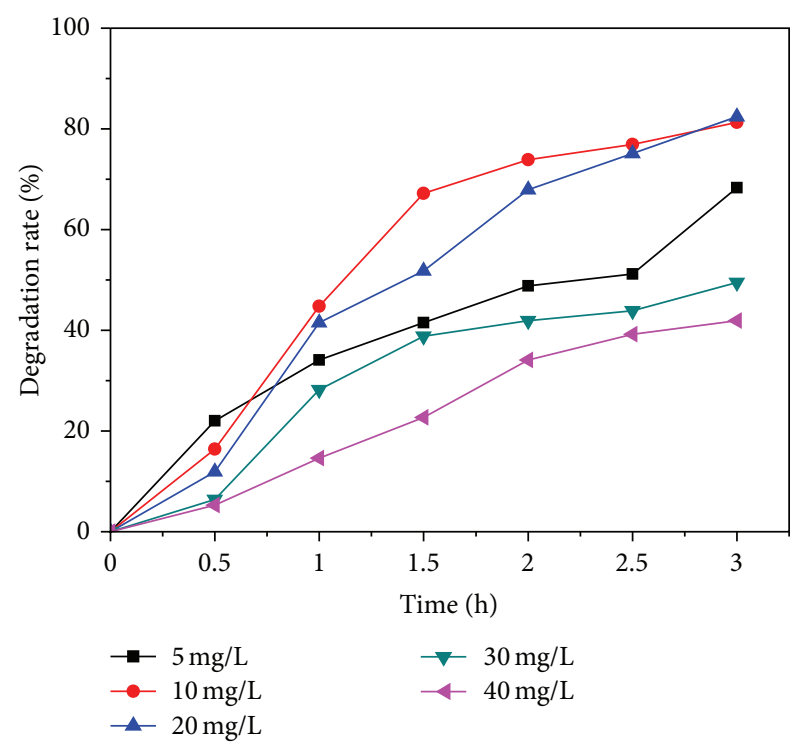

FIGURE 4: Effect of the initial methyl violet concentration on the photocatalytic degradation rate of methyl violet.

As can be seen in Figure 4, the degradation rate decreased with increase of initial concentration of methyl violet. This might be due to the excessive adsorption of the methyl violet molecules on the surface of catalyst at higher concentration. Moreover, light through the solution is reduced significantly. The results indicated that the degradation rate gradually increased with increase of the initial concentration of dye from 5 to $20 \mathrm{mg} / \mathrm{L}$. However, the degradation efficiency gradually decreased with increase of the initial concentration of dye from 20 to $40 \mathrm{mg} / \mathrm{L}$. Thus, the efficiency of degradation was decreased in the higher concentration. From the practical point of wastewater treatment, the initial concentration of the $20 \mathrm{mg} / \mathrm{L}$ is more appropriate.

3.2.3. Effect of $p H$. It is well known that the $\mathrm{pH}$ of the solution is one of the most important parameters in the photocatalytic degradation of organic compounds. This is attributed to the fact that the $\mathrm{pH}$ not only determines chemical properties of the photocatalyst but also influences adsorption behaviour of the pollutants. Therefore, the effect of $\mathrm{pH}$ on the degradation of methyl violet was studied at $\mathrm{pH}$ range from 3.5 to 7.5 .

As shown in Figure 5, the most effective $\mathrm{pH}$ condition is at 5.5. This may be ascribed to the fact that the $\mathrm{pH}$ value could influence the amount of hydroxyl radicals $\left(\mathrm{OH}^{\circ}\right)$ formed and the stable of $\mathrm{H}_{4} \mathrm{SiW}_{12} \mathrm{O}_{40}$. So the optimum $\mathrm{pH}$ of the solution is 5.5 .

3.2.4. Effect of Catalyst Dosage. The catalyst dosage is also an important parameter for optimizing the operational conditions. Therefore, the effect of catalyst dosage on the degradation of methyl violet was investigated in the catalyst dosage from 0.15 to $0.60 \mathrm{~g}$, and the result shown was in Figure 6. The results indicated that the degradation rate gradually increased with increase of catalyst dosage from 0.15 to $0.30 \mathrm{~g}$. However, the degradation efficiency gradually decreased with increase 


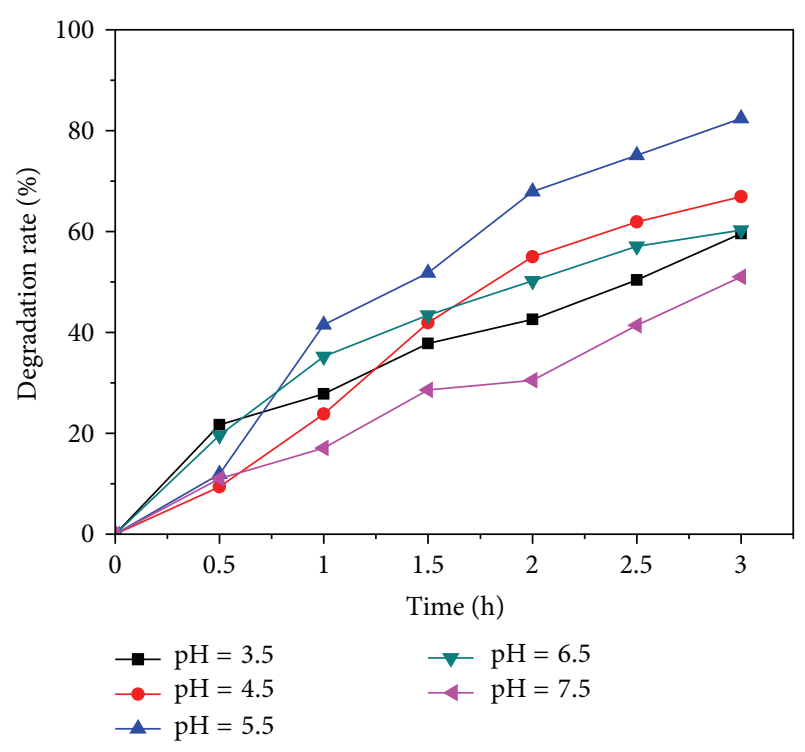

FIGURE 5: Effect of the solution $\mathrm{pH}$ on the photocatalytic degradation rate of methyl violet.

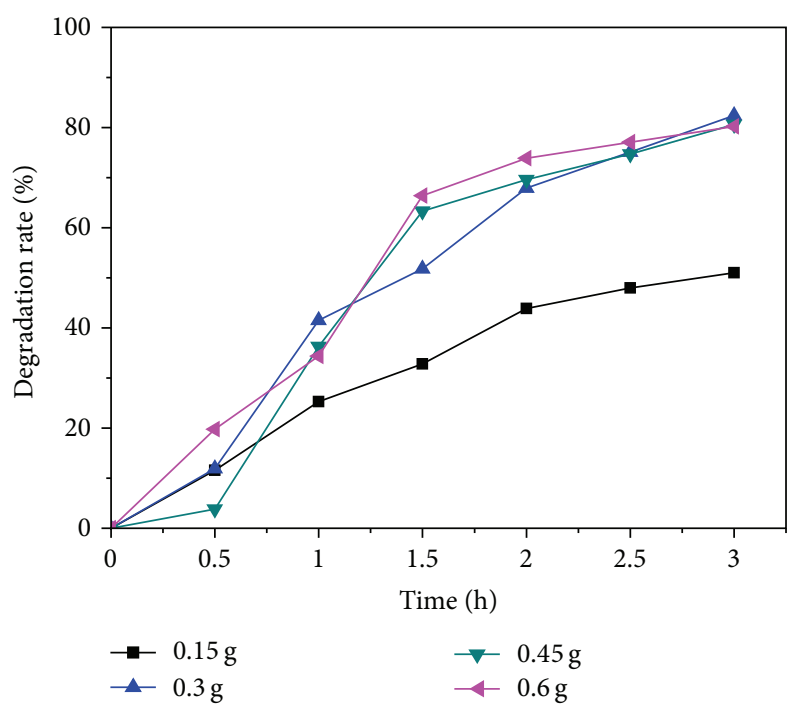

FIGURE 6: Effect of catalyst dosage on the photocatalytic degradation rate of methyl violet.

of catalyst dosage from 0.30 to $0.60 \mathrm{~g}$. This may be attributed to the fact that the surplus catalyst can scatter the photons in the photoreaction system.

3.2.5. Kinetic Analysis. It is well known that the photodegradation of organic dyes mainly follows first-order kinetics. The kinetics of photocatalytic degradation of methyl violet was also studied under optimized conditions. The results are shown in Figure 7.

The results showed that the photocatalytic degradation of methyl violet over $\mathrm{TiSiW}{ }_{12} \mathrm{O}_{40} / \mathrm{TiO}_{2}$ under simulated sunlight irradiation can be described by the first-order kinetic

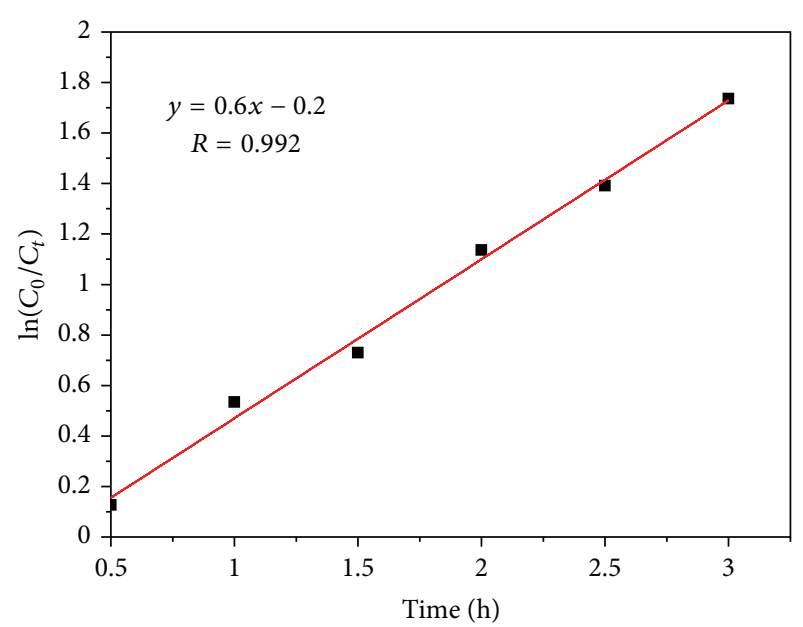

Figure 7: Relation curve of $\ln \left(C_{0} / C_{t}\right)$ and time $(t)$.

model, $\ln \left(C_{0} / C_{t}\right)=k t$, where $k$ is the rate constant $\left(\mathrm{h}^{-1}\right)$, $C_{0}$ is the initial concentration, and $C_{t}$ is the concentration of dye at time $t$. It can be seen from Figure 7 that the plots represented a straight line. The correlation constant for the line was 0.992 . The rate constant was $0.6 \mathrm{~h}^{-1}$.

3.2.6. Comparison of Photocatalytic Activity of Catalysts. The photodegradation rate of $\mathrm{TiSiW}_{12} \mathrm{O}_{40} / \mathrm{TiO}_{2}$ was compared with those of Co-SBA-15 [18], Fe-doped anatase $\mathrm{TiO}_{2}$ [19], $\mathrm{TiO}_{2}$, and $\mathrm{H}_{4} \mathrm{SiW}_{12} \mathrm{O}_{40}$, and the results are shown in Table 1 .

The catalytic activity of $\mathrm{TiSiW}_{12} \mathrm{O}_{40} / \mathrm{TiO}_{2}$ is much higher than that of $\mathrm{H}_{4} \mathrm{SiW}_{12} \mathrm{O}_{40}$ and $\mathrm{TiO}_{2}$ under simulated natural light irradiation. This might be ascribed to the synergistic effect between $\mathrm{H}_{4} \mathrm{SiW}_{12} \mathrm{O}_{40}$ and $\mathrm{TiO}_{2}$. It was also observed that $\mathrm{TiSiW}_{12} \mathrm{O}_{40} / \mathrm{TiO}_{2}$ shows a higher photocatalytic efficiency of degradation dyes than Co-SBA-15, and Fe-doped anatase $\mathrm{TiO}_{2}$. The results indicate that $\mathrm{TiSiW}_{12} \mathrm{O}_{40} / \mathrm{TiO}_{2}$ has an excellent photocatalytic performance with a degradation of methyl violet more than $82 \%$ in $3 \mathrm{~h}$, suggesting that the catalyst $\mathrm{TiSiW}_{12} \mathrm{O}_{40} / \mathrm{TiO}_{2}$ has an excellent application in environmental protection.

\section{Conclusion}

The photocatalytic degradation of methyl violet using $\mathrm{TiSiW}_{12} \mathrm{O}_{40} / \mathrm{TiO}_{2}$ as a novel eco-friendly catalyst under simulated natural light irradiation was investigated. The results demonstrated that at optimal condition (initial concentration of methyl violet is $20 \mathrm{mg} / \mathrm{L}$, catalyst dosage is $0.3 \mathrm{~g}$, and the $\mathrm{pH}$ is 5.5), the degradation rate of methyl violet is as high as $82.4 \%$ after $3 \mathrm{~h}$ under simulated natural light irradiation. The reaction of photocatalysis for methyl violet can be expressed as first-order kinetic mode.

\section{Acknowledgments}

This work was financially supported by the Young and Middle-Aged Natural Science Foundation of Hubei Province 
TABLE 1: Comparison of photocatalytic activity of catalysts.

\begin{tabular}{|c|c|c|c|}
\hline Type of catalyst & Catalyst dosage & Reaction conditions & Degradation rate \\
\hline Co-SBA-15 & $1 \mathrm{~g} / \mathrm{L}$ & $\begin{array}{c}\text { Initial concentration } 50 \mathrm{mg} / \mathrm{L} \text {, within } 150 \mathrm{~min} \text { of solar light } \\
\text { irradiation }\end{array}$ & $61 \%$ \\
\hline Fe-doped anatase $\mathrm{TiO}_{2}$ & $0.18 \mathrm{~g}$ & Initial concentration $4 \mathrm{mg} / \mathrm{L}, \mathrm{pH}$ is 5.5 , within $4 \mathrm{~h}$ visible light & $59.4 \%$ \\
\hline $\mathrm{TiO}_{2}$ & $0.3 \mathrm{~g}$ & $\begin{array}{c}\text { Initial concentration } 20 \mathrm{mg} / \mathrm{L}, \mathrm{pH} \text { is } 5.5 \text {, within } 3 \mathrm{~h} \text { simulated } \\
\text { natural light irradiation }\end{array}$ & $58.8 \%$ \\
\hline $\mathrm{H}_{4} \mathrm{SiW}_{12} \mathrm{O}_{40}$ & $0.3 \mathrm{~g}$ & $\begin{array}{c}\text { Initial concentration } 20 \mathrm{mg} / \mathrm{L}, \mathrm{pH} \text { is } 5.5 \text {, within } 3 \mathrm{~h} \text { simulated } \\
\text { natural light irradiation }\end{array}$ & $21.5 \%$ \\
\hline $\mathrm{TiSiW}_{12} \mathrm{O}_{40} / \mathrm{TiO}_{2}$ & $0.3 \mathrm{~g}$ & $\begin{array}{c}\text { Initial concentration } 20 \mathrm{mg} / \mathrm{L}, \mathrm{pH} \text { is } 5.5 \text {, within } 3 \mathrm{~h} \text { simulated } \\
\text { natural light irradiation }\end{array}$ & $82.4 \%$ \\
\hline
\end{tabular}

Education Department (nos. Q20112507 and Q20082202) and Hubei Key Laboratory of Pollutant Analysis and Reuse Technology (no. KY2010G13).

\section{References}

[1] F. H. Hussein, "Comparison between solar and artificial photocatalytic decolorization of textile industrial wastewater," International Journal of Photoenergy, vol. 2012, Article ID 793648, 10 pages, 2012.

[2] M. N. Chong, B. Jin, C. W. K. Chow, and C. Saint, "Recent developments in photocatalytic water treatment technology: a review," Water Research, vol. 44, no. 10, pp. 2997-3027, 2010.

[3] H. Lachheb, E. Puzenat, A. Houas et al., "Photocatalytic degradation of various types of dyes (Alizarin S, Crocein Orange G, Methyl Red, Congo Red, Methylene Blue) in water by UVirradiated titania," Applied Catalysis B, vol. 39, no. 1, pp. 75-90, 2002.

[4] Q. Zhang, Y. H. Jing, A. Shiue, C.-T. Chang, B.-Y. Chen, and C.C. Hsueh, "Deciphering effects of chemical structure on azo dye decolorization/degradation characteristics: bacterial vs. photocatalytic method," Journal of the Taiwan Institute of Chemical Engineers, vol. 43, no. 5, pp. 760-766, 2012.

[5] C. C. Hsueh and B. Y. Chen, "Comparative study on reaction selectivity of azo dye decolorization by Pseudomonas luteola," Journal of Hazardous Materials, vol. 141, no. 3, pp. 842-849, 2007.

[6] C. McCullagh, N. Skillen, M. Adams, and P. K. Robertson, "Photocatalytic reactors for environmental remediation: a review," Journal of Chemical Technology and Biotechnology, vol. 86, no. 8, pp. 1002-1017, 2011.

[7] S. H. S. Chan, T. Y. Wu, J. C. Juan, and C. Y. Teh, "Recent developments of metal oxide semiconductors as photocatalysts in advanced oxidation processes (AOPs) for treatment of dye waste-water," Journal of Chemical Technology and Biotechnology, vol. 86, no. 9, pp. 1130-1158, 2011.

[8] M. Y. Guo, A. M. C. Ng, F. Liu, A. B. Djurišić, and W. K. Chan, "Photocatalytic activity of metal oxides-the role of holes and $\mathrm{OH} \bullet$ radicals," Applied Catalysis B, vol. 107, no. 1-2, pp. 150-157, 2011.

[9] J. Fenoll, P. Hellin, C. M. Martínez, P. Flores, and S. Navarro, "Semiconductor oxides-sensitized photodegradation of fenamiphos in leaching water under natural sunlight," Applied Catalysis B, vol. 115-116, pp. 31-37, 2012.

[10] L. N. Wang, F. Lu, and F. M. Meng, "Synthesis and photocatalytic activity of $\mathrm{TiO}_{X}$ powders with different oxygen defects," International Journal of Photoenergy, vol. 2012, Article ID 208987, 7 pages, 2012.
[11] X. M. Zhou, J. Y. Lan, G. Liu et al., "Facet-mediated photodegradation of organic dye over hematite architectures by visible light," Angewandte Chemie, vol. 124, no. 1, pp. 182-186, 2012.

[12] H. G. Yu, R. Liu, X. F. Wang, P. Wang, and J. Yu, "Enhanced visible-light photocatalytic activity of $\mathrm{Bi}_{2} \mathrm{WO}_{6}$ nanoparticles by $\mathrm{Ag}_{2} \mathrm{O}$ cocatalyst," Applied Catalysis B, vol. 111-112, no. 28, pp. 326-333, 2012.

[13] X. F. Wang, S. F. Li, H. G. Yu, J. Yu, and S. Liu, " $\mathrm{Ag}_{2} \mathrm{O}$ as a novel visible-light photocatalyst: self-stability and high photocatalytic activity," Chemistry: A European Journal, vol. 17, no. 28, pp. 7777-7780, 2011.

[14] Q. Xiang, J. Yu, W. Wang, and M. Jaroniec, "Nitrogen self-doped nanosized $\mathrm{TiO}_{2}$ sheets with exposed $\{001\}$ facets for enhanced visible-light photocatalytic activity," Chemical Communications, vol. 47, no. 24, pp. 6906-6908, 2011.

[15] P. Lei, C. Chen, J. Yang, W. Ma, J. Zhao, and L. Zang, "Degradation of dye pollutants by immobilized polyoxometalate with $\mathrm{H}_{2} \mathrm{O}_{2}$ under visible-light irradiation," Environmental Science and Technology, vol. 39, no. 21, pp. 8466-8474, 2005.

[16] S. Jiang, Y. Guo, C. Wang, X. Qu, and L. Li, "One-step solgel preparation and enhanced photocatalytic activity of porous polyoxometalate-tantalum pentoxide nanocomposites," Journal of Colloid and Interface Science, vol. 308, no. 1, pp. 208-215, 2007.

[17] E. B. Wang, C. W. Hu, and L. Xu, Polyhydric Chemistry Introduction, Chemical Industry Press, Beijing, China, 1998.

[18] F. Xia, E. Ou, L. Wang, and J. Wang, "Photocatalytic degradation of dyes over cobalt doped mesoporous SBA-15 under sunlight," Dyes and Pigments, vol. 76, no. 1, pp. 76-81, 2008.

[19] Y. Zhang and B. Chen, "Factors of affecting photocatalytic degradation on methyl violet by titania," Applied Chemical Industry, vol. 44, pp. 814-817, 2001 (Chinese). 

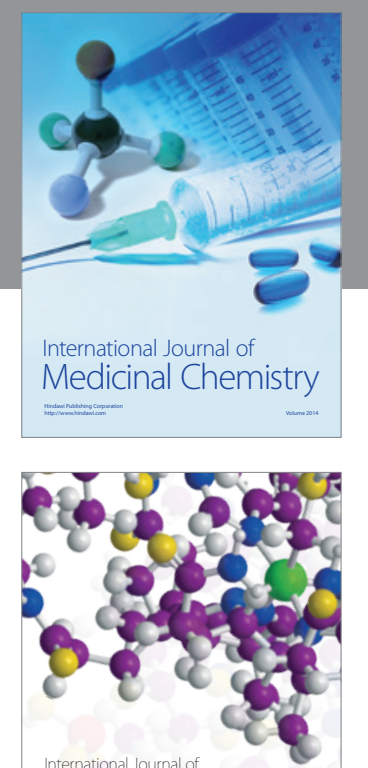

\section{Carbohydrate} Chemistry

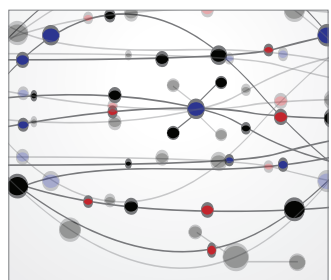

The Scientific World Journal
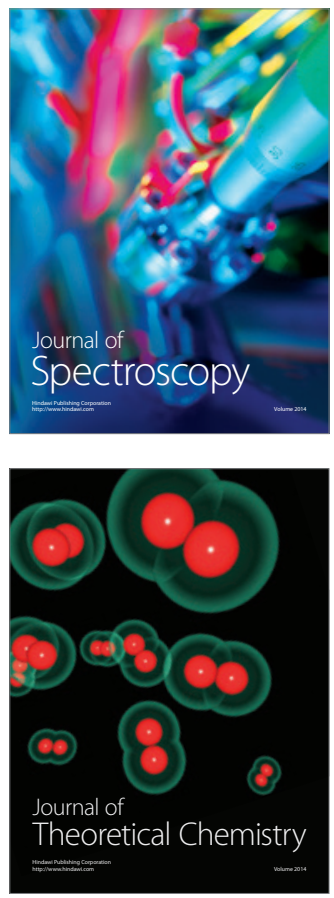
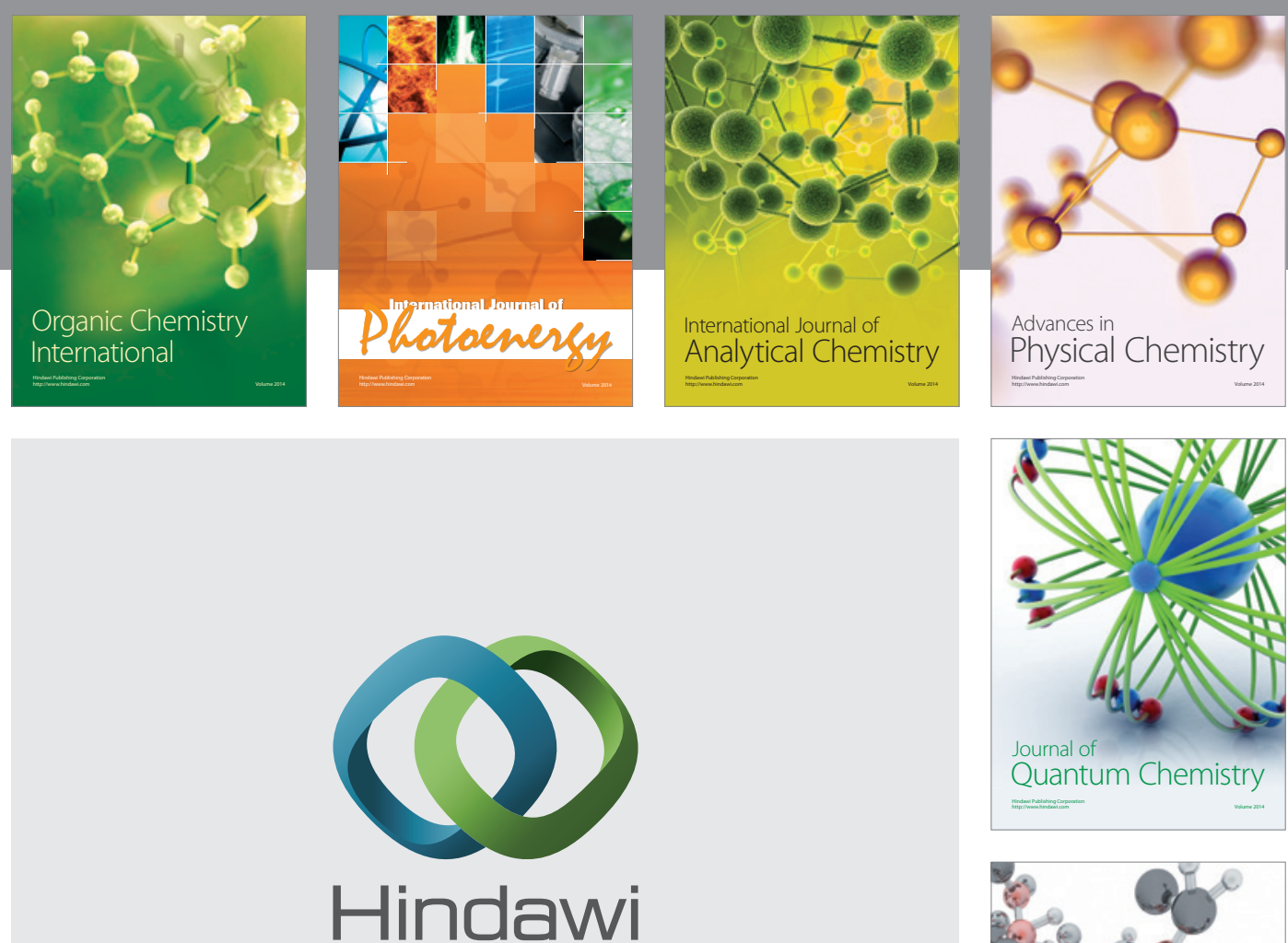

Submit your manuscripts at

http://www.hindawi.com

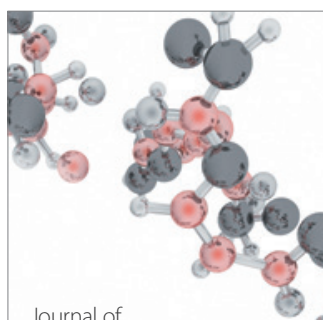

Analytical Methods

in Chemistry

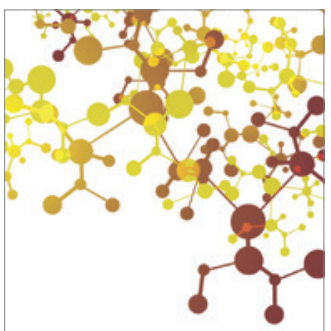

Journal of

Applied Chemistry

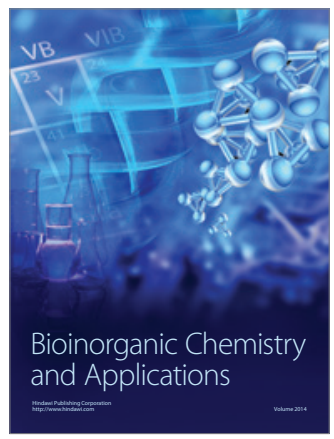

Inorganic Chemistry
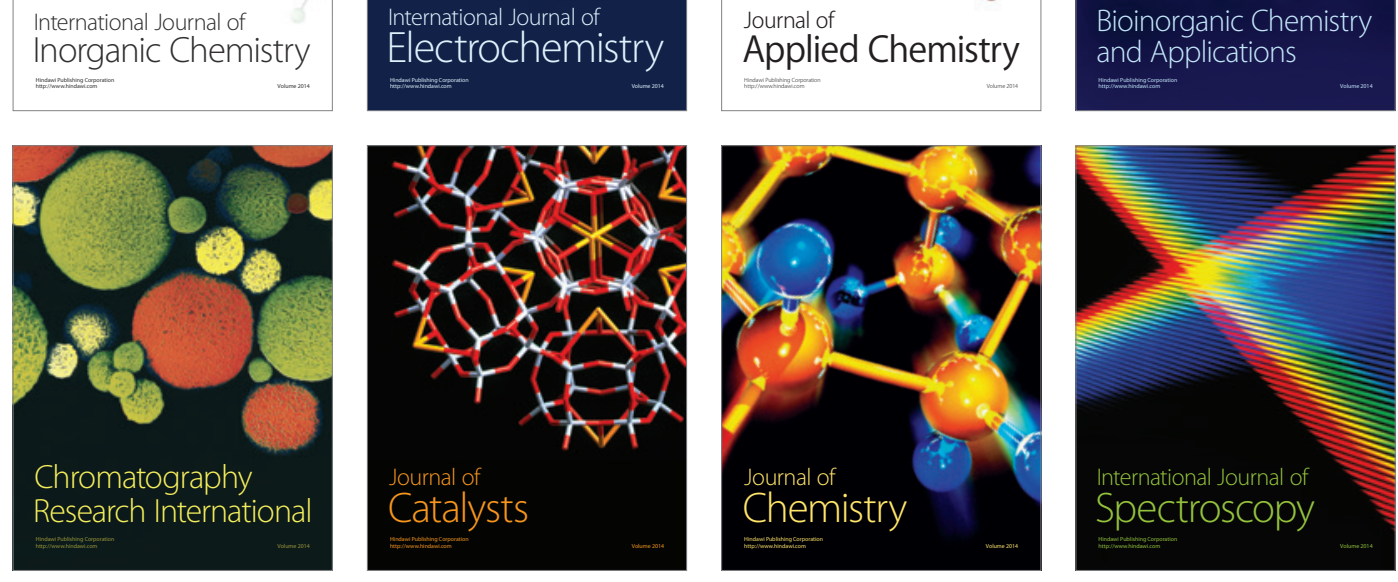